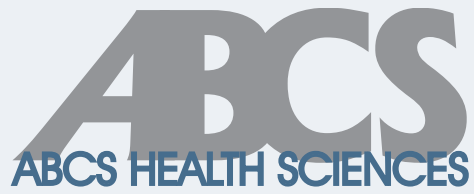

How to cite this article: Bittencourt et al. Epidemiological profile and study on waiting lists for corneal transplants in a tertiary hospital. ABCS Health Sc 2020;45(Suppl.3):e020107. https://doi. org/10.7322/abcshs.2020S07.1854

Corresponding Author: Vagner Loduca Lima - Discipline of Ophthalmology, Centro Universitário FMABC - Avenida Lauro Gomes, 2000 - Sacadura Cabral CEP: 09060-650 - Santo André (SP), Brazil E-mail: vagner@loduca.com.br

Declaration of interest: nothing to declare

This is an open access article distributed under the terms of the Creative Commons Attribution License

(C) 2020 Bittencourt et al.

\title{
Epidemiological profile and study on waiting lists for corneal transplants in a tertiary hospital
}

\begin{abstract}
Jacqueline Lunardelli Bittencourt ${ }^{1}$, Ítala de Mores Vieira Gatti ${ }^{1}$, Carolina Falcão Lessa ${ }^{1}$, Luciano Rabello Netto Cirillo ${ }^{1}$, Mariana Gameiro lerardi ${ }^{1}$, Marina Paulino Gracia ${ }^{1}$, Luiz Antônio de Brito Martins ${ }^{1}$, Fernando Luiz Affonso Fonseca ${ }^{1,2,3}$, Vagner Loduca Lima ${ }^{1}$

${ }^{1}$ Discipline of Ophthalmology. Centro Universitário FMABC - Santo André (SP), Brazil.

${ }^{2}$ Clinical Analysis Laboratory, Centro Universitário FMABC - Santo André (SP), Brazil. ${ }^{3}$ Department of Pharmaceutical Sciences, Universidade Federal de São Paulo (UNIFESP) Diadema (SP), Brazil.
\end{abstract}

\begin{abstract}
Introduction: Epidemiological studies and about patients' waiting time on queues for corneal transplantation are important, as they allow us to know the assisted population and assist the medical team. Objective: To evaluate the epidemiological and demographic profile of patients undergoing corneal transplantation from January 2014 to September 2018 at a teaching hospital in the city of Santo André, as well as their waiting time for the procedure. Methods: Retrospective descriptive study, performed through analysis of medical records and data from the website of the Government of the State of São Paulo's transplant center. The study was conducted at the External and Corneal Diseases sector of the discipline of Ophthalmology from Centro Universitário FMABC. The following data were evaluated: gender, age, race, origin and waiting time for the patient to have a transplant. Results: A total of 139 corneal transplant patients were recruited for the study, with a mean age of $47.4 \pm 23$ years. According to gender, just over half of the transplanted were female (50.4\%). Regarding to skin color, $45.3 \%$ of the patients were white, $44.6 \%$ were brown and $10.1 \%$ were black. As for their origin, most patients were from the city of Santo André. Conclusion: This study enabled the assessment and knowledge of the epidemiological profile and waiting time for corneal transplantation in our patients. This information is important, as it helps us to understand the profile of the assisted population and in the organization and planning of the medical team, contributing to better guidance and care for the patients.
\end{abstract}

Keywords: corneal transplantation; epidemiological profile; corneal transplant row.

\section{INTRODUCTION}

The healthy cornea is a transparent, avascular tissue, intensely innervated, rich in collagen and resistant to trauma. It is responsible for approximately $74 \%$ of the total refractive power of the eye, being essential to maintain a good visual quality ${ }^{1}$. The low visual acuity, secondary to diseases that affect the cornea, represent a high rate of reversible 
blindness in the world. These diseases have different etiologies, among them, degenerative changes, chronic diseases, corneal ectasias, inflammatory, post-surgical, infectious and traumatic diseases ${ }^{2,3}$.

In recent years, there has been a great evolution in eye surgery, including corneal transplantation. The history of corneal procedures may be divided in two eras: the "Age of heteroplasty", from 1800 to 1900, and the "Age of Homoplasty", from 1900. Through animal studies, scientists started to shape and define the reality of a surgery which would become commonplace after a century.

The first lamellar keratoplasty was done by German surgeon Arthur von Hippel in the late 19th century - marking the beginning of the era of modern keratoplasty -, while the first penetrating keratoplasty considered successful was performed at the beginning of the 20th century by Zirm ${ }^{1}$.

Corneal transplantation is able to restore corneal anatomy, structure transparency and vision, thus being an effective treatment for many serious corneal diseases ${ }^{4-6}$. Compared with other organs and tissues, the cornea has a lower rejection rate, which gave rise to the concept of "immune privilege of the cornea". This "immunological privilege" occurs due to its relative isolation from the body's immune system due to the absence of lymphatic vessels and vascularization in the cornea in its normal state.

Modifications and advances in surgical techniques, instruments and equipment, methods of preserving the donor cornea and better postoperative control have also contributed to greater success in corneal transplants ${ }^{7}$.

Corneal transplantation is performed more and more by ophthalmologists in Brazil due to a growing awareness of the population for organ donation and the emergence in the country of new eye banks ${ }^{8,9}$. Another factor responsible for the increasing number of corneal transplants is the better organization of the work carried out by the Eye Banks in which quick notification and preservation allow for a better anatomical condition of the donor cornea ${ }^{10,11}$.

The distribution of corneas in Brazil is conducted by the Central of Notification, Collection and Distribution of State Organs (CNCDO). It obeys the elapsed time of enrollment in a unified list (Ordinance GM no. 3407 of August, 5th 1998), and the date of enrollment of the patient in the unified list is the reference to start the calculation of the overall waiting time. The waiting list is usually statewide, but in some States it can be divided by region. The Eye Bank (EB) is responsible for the approach and capture of corneas and ocular tissues, in conjunction with the Intra-Hospital Transplantation Commissions, and also for the processing, evaluation and correct storage of these tissues, with the State being responsible for distributing the tissues, managing the waiting list, analyzing special cases and emergencies ${ }^{12-14}$.
Epidemiological studies conducted to assess the profile of patients already transplanted or waiting for transplantation are important because they allow the assessment and knowledge of the assisted population. The evaluation of waiting time for corneal transplantation is also a relevant data, as it assists in the organization and planning of the medical team and contributes to better guidance and care for the patients.

The present study aimed to assess the epidemiological and demographic profile and the waiting time of patients undergoing corneal transplantation from January 2014 to September 2018 at a teaching hospital in the city of Santo André (SP).

\section{METHODS}

\section{Design of the study}

This is a retrospective descriptive study. It was conducted by analyzing the patients' medical records and using data from the transplantation center website of the State of São Paulo. The study was conducted in the External and Corneal Diseases sector of the Discipline of Ophthalmology from Centro Universitário FMABC, with information from patients who underwent corneal transplantation (lamellar and penetrating) at Hospital Estadual Mario Covas from January 2014 to September 2018. Medical records of 139 patients were evaluated according to the following data: gender, age, race, origin and waiting time for the transplant (time interval between registration on the transplant list and the date of the procedure). This study was done in accordance with the relevant guidelines and regulations/ethical principles stated by the Declaration of Helsinki.

Inclusion Criteria: Patients undergoing optic corneal transplantation (lamellar and penetrating), except prioritized and tectonic, from January 2014 to September 2018, at Mario Covas State Hospital; complete medical record containing the research data: gender, age, race and origin. We also evaluated the waiting time for the transplant using data from the website of the transplant center of the Government of the State of São Paulo.

Exclusion criteria: Patients with incomplete relevant data in their medical records; Patients with missing medical records.

\section{Statistical analysis}

In the description of the characteristics of the study population, the frequency distribution as well as the absolute and percentage frequencies were presented. Regarding the description of the variables "age" and "waiting time for the transplant", the mean and standard deviation were used in the analysis of the first variable, while the representation by the median and interquartile range were used for the variable waiting 
time (this variable did not present a normal distribution, so the Komogorov-Smirnov normality test was applied). In the analysis of the association of the characteristics of the patients with the waiting time, the Chi-square and Fischer's exact tests were applied to compare the frequencies. In the comparison of medians, the Kruskal-Wallis test was applied. The statistical significance adopted in the study was $5 \%(\mathrm{p}<0.05)$ and the software used was STATA v.14.

\section{RESULTS}

From January 2014 to September 2018, 139 corneal transplant patients were recruited for the study, with a mean age of $47.4 \pm 23$ years. The minimum age was 5 years and the maximum was 87 years. Divided into age groups, in $39.6 \%$ of the transplants patients were 60 years of age or older; $34.5 \%$ were in the 20 to 39 age group, $11.5 \%$ were under 20 and $14.4 \%$ were between 40 and 59 years of age. According to gender, a little more than half of the transplant recipients were female (50.4\%). Regarding race, $45.3 \%$ of the patients were white, $44.6 \%$ were brown and $10.1 \%$ were black. Regarding the provenance of the case, $46.1 \%$ of the patients were from the city of Santo André, 20.9\% from São Bernardo do Campo, 15.8\%

Table 1: Characteristics of patients undergoing optic corneal transplantation, from January 2014 to September 2018, at Mario Covas State Hospital

\begin{tabular}{|c|c|}
\hline Caracteristics & $\mathbf{N}(\%)$ \\
\hline Number of patients & 139 patients \\
\hline \multicolumn{2}{|l|}{ Age range } \\
\hline Under 20 years & $16(11.5 \%)$ \\
\hline From 20 to 39 years & $48(34.5 \%)$ \\
\hline From 40 to 59 yearss & $20(14.4 \%)$ \\
\hline 60 years or more & $55(39.6 \%)$ \\
\hline \multicolumn{2}{|l|}{ Sex } \\
\hline Male & $69(49.6 \%)$ \\
\hline Female & $70(50.4 \%)$ \\
\hline \multicolumn{2}{|l|}{ Race } \\
\hline White & $63(45.3 \%)$ \\
\hline Brown & $62(44.6 \%)$ \\
\hline Black & $14(10.1 \%)$ \\
\hline \multicolumn{2}{|l|}{ Provenance } \\
\hline Santo André & $64(46.1 \%)$ \\
\hline São Bernardo do Campo & $29(20.9 \%)$ \\
\hline Mauá & $22(15.8 \%)$ \\
\hline Ribeirão Pires & $11(7.9 \%)$ \\
\hline Diadema & $6(4.3 \%)$ \\
\hline São Caetano do Sul & $5(3.6 \%)$ \\
\hline Rio Grande da Serra & $1(0.7 \%)$ \\
\hline São Vicente & $1(0.7 \%)$ \\
\hline
\end{tabular}

from Mauá, 7.9\% from Ribeirão Pires, while $8.6 \%$ of the cases corresponded to patients residing in the cities of Diadema, São Vicente, São Caetano do Sul and Rio Grande da Serra (Table 1).

The analysis of the waiting time for a patient to get a transplant, the average found was 8.1 months, with a minimum of 1 month and a maximum of 16.1 months. It is observed that $21.2 \%$ of the patients underwent the transplant in the first 3 months after enrollment, $17.5 \%$ between 3 months and 6 months (in cumulative terms), while $38.7 \%$ of the patients had to wait up to 6 months for the procedure. However, the most frequent waiting time was from more than 6 months to 12 months ( $35.8 \%$ of the cases), while $25.6 \%$ of the patients had to wait for more than 12 months (Figure 1).

When analyzing whether some of the characteristics of the patients are associated with the waiting time, it was observed that none of them showed any association - that is, the waiting time was not influenced by age, gender, race or origin (Table 2).

Comparing the median "waiting time" between the age, gender and race groups, there was also no statistically significant differences found, showing that the waiting time experienced by the patients was not influenced by those characteristics (Figure 2).

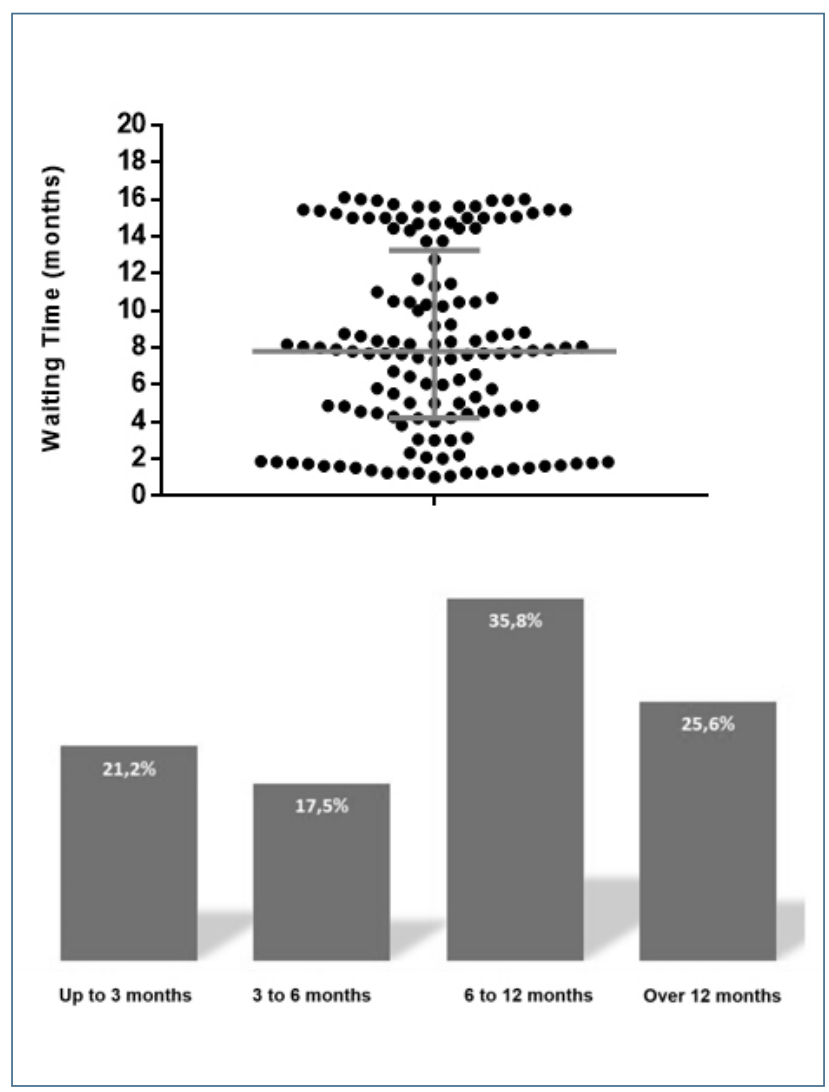

Figure 1: Description of the waiting time for patients for optic corneal transplantation, from January 2014 to September 2018, at Mario Covas State Hospital. 


\section{DISCUSSION}

In our study, the mean age of the patients was $47.4 \pm 23$ years, with a minimum age of 5 years and a maximum age of 87 years, and in $39.6 \%$ of the transplants, the patients were 60 years old or older. Regarding gender, a little more than half of the transplant recipients were female (50.4\%). Regarding race, $45.3 \%$ of the patients were white, $44.6 \%$ were brown and $10.1 \%$ were black. Regarding the waiting time in the transplant queue, the average obtained was 8.1 months, with a minimum of 1 month and a maximum of 16.1 months.

A study carried out in 2006 by Netto et al. showed that $59.6 \%$ of the patients were male and $40.3 \%$ were female, with an average age of 37 years (ranging from 3 to 83 years). According to the origin of the patients, $68 \%$ were from the state of São Paulo, 6\% from the states of Minas Gerais and Paraná, 5\% from Rio de Janeiro, 3\% from Maranhão and 12\% from other states ${ }^{15}$.

Fabris et al. published a study in 2001 in which $60.9 \%$ of patients were male and $39 \%$ female. The age of the sample studied ranged from 3 to 89 years, with a mean age of $42.3 \pm 19.8$ years. The skin color most frequently observed was white, with 74 patients $(89.2 \%)$, followed by black, with 9 cases $(10.8 \%)$. The average waiting time for a corneal donor varied between zero and 39 months, with an average of 17.3 \pm 9.9 months. From this studied transplanted patients, 36 (41.4\%) were from Porto Alegre, 22 (25.3\%) from the municipalities in the metropolitan region of Porto Alegre, 26 (29.9\%) from Rio Grande do Sul's interior, and 3 (3.4\%) from Santa Catarina ${ }^{16}$.

In a study published in 2018 , Bigan et al. ${ }^{17}$ obtained a mean age of patients of $59 \pm 15$ years. In their study on the subject published in New Zealand, Crawford et al. ${ }^{18}$ noted that the age of the patients ranged from 3 to 95 years, with an average of 46.4 years. Regarding gender, $44.2 \%$ were female and $55.8 \%$ were male. Here, it was observed that $58.3 \%$ of the transplant patients were European, $11.9 \%$ Maori, $18.7 \%$ from the Pacific, $6.5 \%$ from India and $4.4 \%$ from other regions.

A study carried out in 2016, Belghmaidi et al. ${ }^{19}$ showed that $51.3 \%$ of the patients were male and $48.6 \%$ female. The mean age was 34 years, with extremes ranging from 6 to 85 years. In a study published in 2018 by Fonseca et al., 55.5\% of the evaluated patients were male and $44.5 \%$ were female. The mean age was $46.7^{20}$.

In a 2016 publication, Almeida et al. ${ }^{21}$ observed that $54 \%$ of the patients were female and 35\% were between 61 and 80 years old; the average waiting time in the transplant queue most often found ranged from 1 to 6 months.

In their work published in 2014, Araujo et al. showed that there was no statistically significant difference between the frequency of both genders, being $52.2 \%$ of the patients male and $47.8 \%$ female. The average age group was 52.1 years, with 1 year being the lowest age and 90 the largest. The average waiting time in the transplant queue was 6.28 months.

Table 2: Description of the waiting time and characteristics of patients undergoing optic corneal transplantation, from January 2014 to September 2018, at Mario Covas State Hospital.

\begin{tabular}{|c|c|c|c|c|c|}
\hline Characteristics & $\begin{array}{l}\text { Up to } 3 \text { months } \\
(n=29)\end{array}$ & $\begin{array}{l}\text { Up to } 6 \text { months } \\
\qquad(n=24)\end{array}$ & $\begin{array}{c}\text { From } 6 \text { to } 12 \\
\text { months } \\
(n=49)\end{array}$ & $\begin{array}{c}\text { More than } 12 \\
\text { months } \\
(n=35)\end{array}$ & p-value \\
\hline \multicolumn{6}{|l|}{ Age range } \\
\hline Under 20 years & $3(18.7 \%)$ & $1(6.2 \%)$ & $8(50 \%)$ & $4(25.0 \%)$ & \multirow{4}{*}{$0.385^{a}$} \\
\hline From 20 a 39 years & $13(27.1 \%)$ & $6(12.5 \%)$ & $15(31.2 \%)$ & $14(29.2 \%)$ & \\
\hline From 40 to 59 years & $2(10.0 \%)$ & $6(30.0 \%)$ & $5(25.0 \%)$ & $7(35.0 \%)$ & \\
\hline 60 years or more & $11(20.7 \%)$ & $11(20.7 \%)$ & $21(39.6 \%)$ & $10(18.9 \%)$ & \\
\hline \multicolumn{5}{|l|}{ Sex } & \multirow{3}{*}{0.549} \\
\hline Men & $17(24.6 \%)$ & $12(17.4 \%)$ & $21(30.4 \%)$ & $19(27.5 \%)$ & \\
\hline Women & $12(17.6 \%)$ & $12(17.6 \%)$ & $28(41.2 \%)$ & $16(23.5 \%)$ & \\
\hline \multicolumn{5}{|l|}{ Race } & \multirow{4}{*}{$0.353^{a}$} \\
\hline White & $16(26.2 \%)$ & $12(19.7 \%)$ & 19 (31.1\%) & $14(23.0 \%)$ & \\
\hline Brown & $12(19.3 \%)$ & $10(16.1 \%)$ & $21(33.9 \%)$ & $19(30.7 \%)$ & \\
\hline Black & $1(7.1 \%)$ & $2(14.3 \%)$ & $9(64.3 \%)$ & $2(14.3 \%)$ & \\
\hline \multicolumn{5}{|l|}{ Provenance } & \multirow{9}{*}{0.971} \\
\hline Santo André & $15(23.8 \%)$ & $11(17.5 \%)$ & $18(28.6 \%)$ & $19(30.2 \%)$ & \\
\hline São Bernardo do Campo & $5(17.2 \%)$ & $5(17.2 \%)$ & $12(41.4 \%)$ & $7(24.1 \%)$ & \\
\hline Mauá & $4(19.0 \%)$ & $4(19.0 \%)$ & $9(43.0 \%)$ & $4(19.0 \%)$ & \\
\hline Ribeirão Pires & $2(18.2 \%)$ & $2(18.2 \%)$ & $4(36.4 \%)$ & $3(27.3 \%)$ & \\
\hline Diadema & $1(16.7 \%)$ & $0(0 \%)$ & $3(50.0 \%)$ & $2(33.3 \%)$ & \\
\hline São Caetano do Sul & $1(20.0 \%)$ & $2(40.0 \%)$ & $2(40.0 \%)$ & $0(\%)$ & \\
\hline Rio Grande da Serra & $0(\%)$ & $0(\%)$ & $1(100 \%)$ & $0(\%)$ & \\
\hline São Vicente & $1(100 \%)$ & $0(\%)$ & $0(0 \%)$ & $0(\%)$ & \\
\hline
\end{tabular}

a Fisher's exact test 

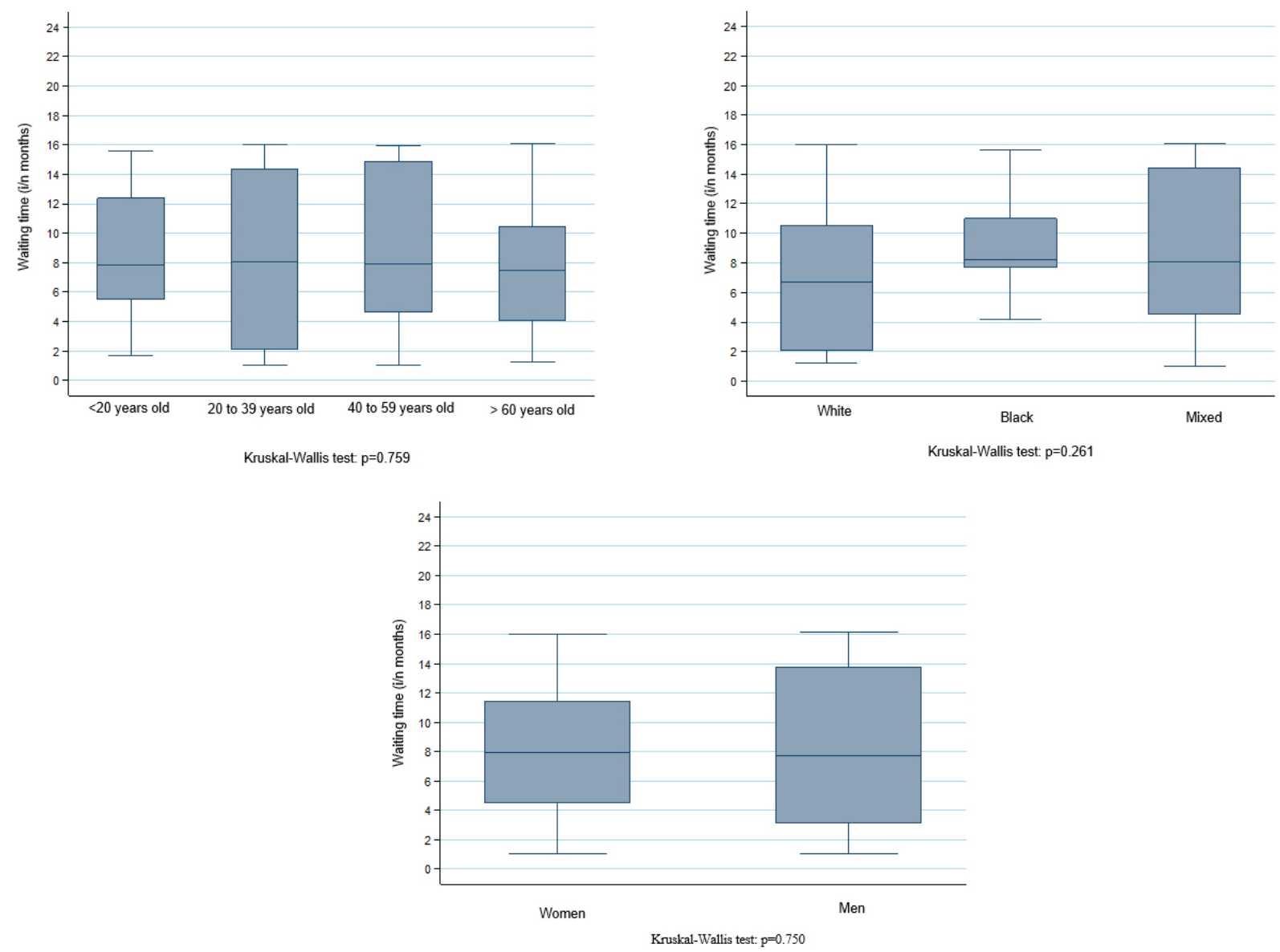

Figure 2: Comparison of waiting time for optical corneal transplantation according to the characteristics of patients (age, gender and race) who underwent optical corneal transplantation, between January 2014 and September 2018, at Mario Covas State Hospital.

As for the waiting time in the transplant queue, the research made by Fabris et al. ${ }^{16}$ indicated an average of $17.3 \pm 9.9$ months; Almeida et al. ${ }^{21}$ research showed the period from 1 to 6 months as the most frequent time; Araujo et al. ${ }^{22}$ obtained an average time of 6.28 months. In our study, the average waiting time was 8.1 months, similar to the time found in the literature.

\section{Conclusion}

This study enabled the assessment and knowledge of the epidemiological profile of our patients and their queue time waiting for corneal transplantation. This information is important, as it helps us to understand the profile of the assisted population and in the organization and planning of the medical team, contributing to better guidance and care to those patients.

\section{REFERENCES}

1. Höfling-Lima AL, Nishiwaki-Dantas MC, Alves MR. CBO: Série oftalmologia Brasileira: doenças externas oculares e córnea. 3 ed. Rio de Janeiro: Guanabara Koogan, 2013.

2. Natarajan S. A close look at cornea. Indian J Ophthalmol. 2014;62(4):381-2.

http://doi.org/10.4103/0301-4738.132102
3. Albert DM, Gamm DM. Cornea: anatomy. Available from: https:// www.britannica.com/science/cornea

4. Brunette I, Roberts CJ, Vidal F, Harissi-Dagher M, Lachaine J, Sheardown $\mathrm{H}$, et al. Alternatives to eye bank native tissue for corneal stromal replacement. Prog Retin Eye Res. 2017;59:97130.

http://doi.org/10.1016/j.preteyeres.2017.04.002 
5. Tan DTH, Dart JKG, Holland EJ, Kinoshita S. Corneal transplantation. Lancet. 2012;379(9827):1749-61. http://doi.org/10.1016/S0140-6736(12)60437-1

6. Ple-Plakon PA, Shtein RM. Trends in corneal transplantation: indications and techniques. Curr Opin Ophthalmol. 2014;25(4):3005 . http://doi.org/10.1097//CU.0000000000000080

7. Kamp MT, Fink NE, Enger C, Maguire MG, Stark WJ, Stulting RD. Patient reported symptoms associated with graft reactions in highrisk patients in the collaborative corneal transplantation studies. Collaborative Corneal Transplantation Studies Research Group. Cornea. 1995;14(1):43-8.

8. Dobbins KR, Price Jr FW, Whitson WE. Trends in the indications for penetrating keratoplasty in the midwestern United States. Cornea. 2000;19(6):813-6. http://doi.org/10.1097/00003226-200011000-00010

9. Inoue K, Amano S, Oshika T, Sawa M, Tsuru T. A 10-year review of penetrating keratoplasty. Jpn J Ophthalmol. 2000;44(2):139-45. http://doi.org/10.1016/s0021-5155(99)00190-2

10. Chalita MRC, Diazgranados EBM, Sato EH, Branco BC, Freitas D. Rejeição corneana pós transplante de córnea: análise de dados do Banco de Olhos do Hospital São Paulo - Escola Paulista de Medicina. Arq Bras Oftalmol. 2000;63(1):55-8. https://doi.org/10.1590/S0004-27492000000100011

11. Pereira MLM, Passos MC, Santos AMC, Pecego JG. Normas médicas em Bancos de Olhos: controvérsias. Rev Bras Oftalmol. 2002;61(3):163-7.

12. Brasil. Câmara dos Deputados. Lei $n^{\circ} 9.434$, de 4 de fevereiro de 1997. Dispõe sobre a remoção de órgãos, tecidos e partes do corpo humano para fins de transplante e tratamento e dá outras providências. Available from: https://www2.camara.leg.br/legin/ fed/lei/1997/lei-9434-4-fevereiro-1997-372347-norma-pl.html

13. Brasil. Presidência da República. Decreto $n^{\circ} 2.268$, de 30 de junho de 1997. Regulamenta a Lei no 9.434, de 4 de fevereiro de 1997, que dispõe sobre a remoção de órgãos, tecidos e partes do corpo humano para fim de transplante e tratamento, e dá outras providências. Available from: http://www. planalto.gov.br/ccivil_03/ decreto/1997/D2268impressao.htm

14. Diário Oficial Poder Executivo Estado de São Paulo. Saúde: Gabinete do Secretário. Resolução SS n ${ }^{\circ}$ 114, de 29 de setembro de 2014. Dispõe sobre a estrutura organizacional e operacional do Sistema Estadual de Transplantes de São Paulo. Available from: http://www.saude.campinas.sp.gov.br/saude/lista_legislacoes/ legis_2014/E_R-SS-114_290914.pdf

15. Calix Netto MJ, Giustina ED, Ramos GZ, Peccini RFC, Sobrinho M, Souza LB. Major indications for corneal penetrating keratoplasty at a reference service in São Paulo state (Sorocaba /SP, Brazil). Arq Bras Oftalmol. 2006;69(5):661-4. https://doi.org/10.1590/S0004-27492006000500007

16. Fabris C, Corrêa ZMS, Marcon AS, Castro TN, Marcon IM, Pawlowski C. Estudo retrospectivo dos transplantes penetrantes de córnea da Santa Casa de Porto Alegre. Arq Bras Oftalmol. 2001;64(5):449-53.

https://doi.org/10.1590/S0004-27492001000500014

17. Bigan G, Puyraveau M, Saleh M, Gain P, Martinache I, Delbosc B, et al. Corneal transplantation trends in France from 2004 to 2015: A 12-year review. Eur J Ophthalmol. 2018;28(5):535-40. https://doi.org/10.1177/1120672118762224

18. Crawford AZ, McKelvie J, Craig JP, McGhee CNJ, Patel DV Corneal Transplantation in Auckland, New Zealand, 1999-2009: Indications, Patient Characteristics, Ethnicity, Social Deprivation, and Access to Services. Cornea. 2017;36(5):546-52. https://doi.org/10.1097//CO.0000000000001159

19. Belghmaidi S, Hajji I, Soummane H, Ennassiri W, Essafi $H$, Moutaouakil A. Corneal transplantation: study carried out at the Department of Ophthalmology, University Hospital Center Mohammed VI, Marrakech. Pan Afr Med J. 2016;23:158. https://doi.org/10.11604/pamj.2016.23.158.8667

20. Fonseca BA, Marcos AAA, Leite Filho LAM. Ceratoplastias penetrantes realizadas em serviço oftalmológico de referência revisão dos resultados e complicações. Rev Bras Oftalmol. 2018;77(6):342-4 https://doi.org/10.5935/0034-7280.20180074

21. Almeida HG, Souza ACD. Perfil epidemiológico de pacientes na fila de transplante de córnea no estado de Pernambuco, Brasil. Rev Bras Oftalmol. 2014;73(1):28-32. https://doi.org/10.5935/0034-7280.20140006

22. Araújo AA, Melo GB, Silva RL, Araújo Neta VM. Perfil epidemiológico dos pacientes na lista de espera para transplante de córnea no Estado de Sergipe. Arq Bras Oftalmol. 2004;67(4):613-6. https://doi.org/10.1590/S0004-27492004000 